\title{
The Dollar Dominance : Recent Episode of Trade Invoicing and Debt Issuance
}

\author{
Adrien Faudot \\ Centre de Recherche en Economie de Grenoble, Grenoble, France \\ Jean-François Ponsot \\ Centre de Recherche en Economie de Grenoble, Grenoble, France
}

\begin{abstract}
The international monetary system is known to be asymmetric given the dominant use of a few international currencies. The international trade of developing countries is mainly invoiced in US dollars, unlike industrialized countries which invoice a much higher share of their exports in their home currencies. The same logic is at work in the issuance of international debt. While the attempts to challenge the supremacy of the US dollars have failed in most cases, China is coming to the fore and is increasing its use of the Renminbi, even supported by its growing recognition within the International Monetary Fund. By reassessing the relevance of existing academic works, this paper demonstrates how monetary asymmetries have been reinforced in recent decades, and offers explanations related to currency choices. Finally, this paper offers the conclusion that international monetary reform is necessary. One cannot overlook that the monetary system embodies a major constraint on the sovereignty of developing countries and that some developing countries have set out to challenge the US dollar usage.
\end{abstract}

\footnotetext{
* Corresponding Author: Adrien Faudot; Centre de Recherche en Economie de Grenoble (CREG), BATEG, Bureau 402, Univ. Grenoble Alpes, CS 40700, 38058 Grenoble Cedex 9, France ; Tel: +33 476825402, E-mail: adrien.faudot@, univ-grenoble-alpes.fr.

Co-author: Jean-François Ponsot; Centre de Recherche en Economie de Grenoble (CREG), Univ. Grenoble Alpes, CS 40700, 38058 Grenoble Cedex 9, France; Tel: +33 476827883, E-mail: jean-francois.ponsot@univ-grenoble-alpes.fr. 
JEL Classifications: B22, F14, F36, F65

Keywords: Currency Hierarchy, Grassman's Law, Original Sin, International Monetary System

\section{Introduction}

Monetary relations are asymmetric since the actors involved in globalization only use a handful of national currencies in their cross-border operations, particularly the US Dollar (USD). The impact of asymmetric monetary practices is significant: not only is the country issuing the international currency known to derive enormous benefits from the widely-discussed exorbitant privilege, but conversely most of the world and, developing countries in particular, is constrained by using a foreign currency.

This paper focuses on two aspects illustrating of the asymmetry of monetary practices: international trade invoicing on the one hand and international debt issuance on the other hand. In both sectors, the US Dollar is as of now the most widely used currency, especially in developing countries. With regard to international trade invoicing, we owe the first empirical study to Grassman (1972) who revealed the main pattern of invoicing and provided some ground-breaking insights. International debt issuance has been the object of many studies, the most acclaimed of which was that conducted by Eichengreen, Hausmann, and Panizza (2002). As these works suggest, developing countries denominate their cross-border trade and their international debt in top foreign currencies (Cohen 2000) - mainly the US Dollar - while most industrialized countries use their own currencies. The aim of this paper is to reassess the above-mentioned works, as well as the implications of asymmetry in international monetary practices. As a matter of fact, it is worth noting that monetary practices regarding trade invoicing and debt issuance follow the same trend. The US Dollar has been markedly gaining strength since the 1970s. Moreover, it should be noted that developing countries which attempted to break away from the US Dollar by devising alternative monetary practices relying on their own national currencies have not been successful in their efforts. Still, the monetary system is undergoing internal changes: of particular relevance today is the surge of the Chinese Renminbi (RMB), predicted to reach the status of a second-rank currency.

The paper is structured as follows. Section II explores and revisits Grassman's Law 
in the light of the latest developments in trade invoicing practices. Section III of the paper deals with the issuance of international debt and Original Sin. The supremacy of the US Dollar is increasingly questioned by developing countries through recent attempts to denominate their international debts in their own currencies. Finally, Section IV concludes.

\section{The Issue of International Trade Invoicing}

As international trade involves money transfers, the currency of choice has been the object of several studies in international economics. In his seminal contribution (1973), Grassman identifies a number of trends determining invoicing choices in international exchanges.

\section{A. Grassman's law}

Grassman's law is usually mentioned in works addressing the choice of currency in international trade, and is still extensively referred to today. In 1968, Sven Grassman aims to show that in an exchange involving two industrialized or so-called developed countries, the currency of the exchange for goods and services will most likely be that of the exporter about two thirds of the transactions. This is a symmetric relation. Swedish imports are invoiced in the currency of the exporter in the same order of magnitude, and a much smaller portion is denominated in Swedish kronor. The author goes on to extrapolate on the data as the study on Swedish firms is considered robust and it is partly because data on the invoicing currency in international trade are extremely scarce. For example, data gathered in the same period on Germany and Denmark fully support the Grassman's thesis. 
Table 1. Denomination of Swedish trade in 1968

( $\%$ of total)

\begin{tabular}{|c|c|c|c|}
\hline Currency & $\begin{array}{c}\text { Exporting country's } \\
\text { currency }\end{array}$ & $\begin{array}{c}\text { Importing country's } \\
\text { currency }\end{array}$ & The third currency \\
\hline Swedish exports & 66 & 25 & 9 \\
\hline Swedish imports & 59 & 26 & 15 \\
\hline
\end{tabular}

(Source) Grassman (1973).

Grassman therefore dismisses that the US Dollar reigned supreme in international trade. His observations bring to light the use of the exporter's currency in most of its transactions for exchanges involving developed countries.

The author's conclusion on the lack of international currency is no longer valid in the light of his own statistics regarding developing countries. For these countries, the USD is usually the norm, as noted by Tavlas (1991). Finally, the United States (US) constitutes an exception, along with the United Kingdom (UK) to a lesser extent, due to the status of both the pound sterling and the US Dollar as reserve currencies, which is why both imports from and exports to the United States are usually invoiced in US Dollar ${ }^{1}$. A global perspective on exchanges taking developing countries into consideration helps to somewhat qualify Grassman's conclusions. Only a fraction of the world, the so-called developed countries, can afford to avoid invoicing predominantly in US Dollar, while by contrast international trade involving developing countries is almost fully dollarized. The hierarchical layout of currencies available for international trade is thus reflected in the ways in which international trade can be envisioned as one of the expressions of monetary sovereignty, of which developing countries are deprived.

\section{B. Dollar dominance in international trade invoicing}

With several decades of hindsight, it appears that monetary practices have neither moved towards a rebalancing in favor of the currencies of developing countries nor away from the US Dollar, indeed quite the reverse has occurred. Industrialized countries have

\footnotetext{
${ }^{1}$ At the time of writing, Grassman had only detailed trade data on Sweden, but was able to look at Swedish exports to the US, which were for the most part invoiced in USD, not in Sweden's national currency, as was the case for most of its Western partners.
} 
preserved the ability to invoice in their own currencies, a fact confirmed by the database shared by Kamps (2006). In 2012, recourse to the euro by eurozone members exporting outside the eurozone amounted to $60 \%{ }^{2}$. The principles laid down by Grassman are therefore proven to be correct. However, it should not be overlooked that the US Dollar has been gaining ground in several developed countries like France: the share of US Dollar in France's exports rose from 9\% in 1974 to $18.6 \%$ in 1995 and reached $38.5 \%$ in $2012^{3}$. In most other developed countries, the majority of exports are invoiced in US Dollar: in 2009, over three-quarters of Australia's exports were invoiced in US Dollar. New Zealand also exports mainly in US Dollar (Fabling and Sanderson 2015), and so does Japan (Ito and alii 2010). The international trade of Canada, a country neighboring the US, is mainly invoiced in US Dollar. Even Sweden, which served as the reference to Grassman's work, saw its share of Swedish krona collapse (Wilander 2006, Friberg and Wilander 2008). The krona only accounted for 30\% of Sweden's exports in 2012 according to Eurostat. Clearly, many developed countries have come to have gradually lost some of their ability to invoice in their own currencies. As for developing countries, the data collected by Kamps (2006) suggest that the USD has retained a strong position, an impression corroborated by the most recent data available at the time of writing (Lai and Yu 2014). Likewise, Ito and Chinn (2014) emphasize that over 80\% of Asian exports are still invoiced in US Dollar, except for Japan. The US Dollar also prevails in Latin America, as reflected by Brazil, which denominated over 94\% of its exports in 2011 in US Dollar (Reiss 2014).

\section{Struggles of developing countries}

In the past, Grassman (1973) noted that developing countries differed in their invoicing practices from developed countries for two main reasons: in many cases, their currencies are not convertible, and secondly their export structures are dominated by primary products. The former is logically perceived as a serious drawback for developing countries: if access to the national currency is restricted or impossible for trading partner, it cannot be considered viable for invoicing exchanges between two parties, who will agree on a vehicle currency. The financial structures in these countries are relatively

\footnotetext{
According to Eurostat.

${ }^{3}$ Dunajewski (1985) for data regarding 1974, Bekx (1998) regarding 1995, Eurostat for 2012.
} 
vulnerable, which requires governments to exercise control over their capital accounts and prevent the convertibility of the national currency for the rest of the world. Such restrictions are often necessary for the stability of those countries where financial systems are immature (McKinnon and Schnabl 2014).

Developing countries are usually more specialized in primary products. The homogeneity of these products implies that competition is driven by prices only. For the producer, exchange rate movements are crucial. Exporters have a strong incentive to be in line with their competitors, and to invoice their products in a vehicle currency of a large outlet market. Moreover, commodity prices are particularly volatile, especially when compared with the prices of manufactured goods (UNCTAD 2014). Such volatility can be explained to a large extent by the lack of elasticity of supply as well as demand. Producers in developing countries are left with no choice. In order to stabilize their income, they need to resort to hedging instruments. They need financial services, the most suitable of which are available in very few currencies, with the US Dollar topping them all ${ }^{4}$. A hedging instrument of exchanges functions as an insurance that buyers and sellers need. Sales contracts for raw materials are largely organized around the futures and options markets, where price volatility is often observed (Calabre 1986). That is how actors from developing countries are pushed towards adopting the US Dollar standard and are assimilated into globalized trade and its corollary of financial globalization (Smith 2009).

A third reason may be added to the first two, based on the observation that a great deal of international trade originates from multinational firms. These are still largely Western or the US firms. These firms tend to invoice all of their exchanges in the same currency, regardless of the place of their production sites, which as a rule is the currency of their countries of origin (Benguria and Wagner 2012). The increasing fragmentation of global production did not result in a diversification of international monetary practices.

Globalization sucks new players into international trade, but what they adopt is existing monetary conventions.

\section{Monetary challenges}

All currencies are endowed with an inclusive quality in international trade, which

\footnotetext{
${ }^{4}$ "For some currencies no functioning forward market exists, and so when forward transactions have to be effected it is necessary to use some generally accepted currencies" (Grassman 1973).
} 
unites the community of traders together. This notion of inclusive quality is akin to the coalescing effect expounded by international macroeconomists (Ito and Chinn 2014). It is reinforced by the observation of the difficulties faced by developing countries in their efforts to break free from the dollar standard. Most developing countries are still using the US Dollar, regardless of their diplomatic relations with the US. It is useful at this point to bear in mind that the Union Socialist Soviet Republics (USSR) made frequent use of the US Dollar when trading with the West ${ }^{5}$. Currency generates membership regardless of existing conflicts between commercial actors.

Attempts by emerging countries to make favorable changes in the international monetary regime by trying to promote currencies other than the US Dollar have so far failed. One can find evidence of such failures in Iraq's past, when Saddam Hussein, shortly before his overthrow, began to invoice Iraqi oil in euros or Iran until recently, where the oil bourse uses non-dollar currencies like the euros has experienced significant difficulties (Looney 2004, Idem 2007).

Additionally, the wave of Latin American heads of state who espoused the doctrine of the Bolivarian Left and rose to power in the 2000s have expressed the wish to sever their well-established ties with the US Dollar (Feige et al. 2003). Their desire to be liberated from the US Dollar through a credible alternative route has not been realized. Venezuela has sought to challenge the role of the US Dollar in Latin America. The Sistema Unitario de Compensacion Regional de Pagos (SUCRE) plan was launched in January 2010 and brought together the eight members of the Bolivarian Alliance for the Americas with Uruguay also joining in March 2013. It promoted a system of regional payments, based on a common unit of account which means that transactions between the member states would not have to use the US Dollar (Gnos, Monvoisin and Ponsot 2010). As noted by Labaqui (2014), in practice, neither the Banco del Sur nor the SUCRE has yet materialized it in any meaningful fashion.

The examples discussed above all involve public actors with ties to the oil industry since the oil contracts signed by these countries involve their governments and are more widely publicized, but also because the issue of the currency used by public actors raises public awareness of the importance of economic sovereignty. Even for private actors in the same developing countries, the US Dollar standard constitutes a non-negligible hurdle, since it requires them to purchase dollar supplies, which makes an operation more costly than if it had been made in the national currency. Foreign exchange

\footnotetext{
${ }^{5}$ Dunajewski (1985). It is agreed that the Soviet currency was not convertible.
} 
fluctuations are a real constraint on pricing as well as revenue forecasts. Unloved as it may be, the US Dollar still remains the international monetary standard, particularly for developing countries ${ }^{6}$. Moreover, developing countries are not the only ones to fail in this respect. The developed countries expected to become the future issuers of a credible rival currency have never been in a position to compete with the US Dollar (Pansot 2016, Faudot 2015). In the past, the Deutsche mark, the yen and the euro have all in turn been erroneously identified as potential challengers (Cohen 2014). These failures have revealed that bare political opposition to the US was grossly insufficient to set in motion a dynamics of real changes in national and regional monetary practices (Norrlof 2010)

\section{E. The case of renminbi}

As opposed to the examples studied above, the RMB seems likely to move up in the hierarchy of currencies. The internationalization of the RMB is a statistical reality, based on a gradual process of liberalization which is politically controlled and is tested first on a local scale through pilot schemes. The RMB came to existence with the advent of the People's Republic of China several decades ago, but its spread beyond China emerged, as a response to the dollar shortage caused by the financial panic at the wake of global financial crisis in 2008 which crippled international trade. This expansion can furthermore be explained by a long period of sustained growth of the Chinese economy. In fact, it seems that invoicing practices are shifting towards a greater use of the RMB by international agents. Admittedly, the RMB is not convertible, which is a genuine hurdle to its internationalization a genuine hurdle to its internationalization. China is facing strong external pressures of massive hot money inflows in the environment of very low interest rates to be found in industrialized countries. The maintenance of capital controls appears necessary for the sake of financial stability, even if it hinders RMB internationalization (McKinnon and Schnabl 2014). However, the Chinese currency is becoming increasingly accessible, as it has established a presence in a growing number of key areas in the world. Its use is now encouraged by the executives, particularly for trade, who have undertaken the design of the settlement infrastructure necessary for the internationalization of the RMB (Rhee and Sumulong 2013). As noted by Prasad

\footnotetext{
${ }^{6}$ As noted by Ronald McKinnon (2013), "although nobody loves the dollar standard, the revealed preference of both governments and private participants in the foreign exchange markets since 1945 has been to continue to use it. It is a remarkable survivor that is too valuable to loose and too difficult to replace."
} 
(2014), RMB invoicing is more common for Chinese imports as there is demand for this currency by non-residents. That is one way of taking RMB out of China. Indeed, in the second quarter of 2014, out of the 3.27 trillion RMB cross-border trade settlement, 1.23 trillion RMB were used for exports and 2.04 trillion RMB for imports (People's Bank of China, PBoC 2014). An ever larger amount of Chinese exports are nevertheless invoiced in RMB each year, leading to a rapid growth of RMB-settled international trade.

Figure 1. Monthly RMB cross-border trade settlement

(billions of RMB)

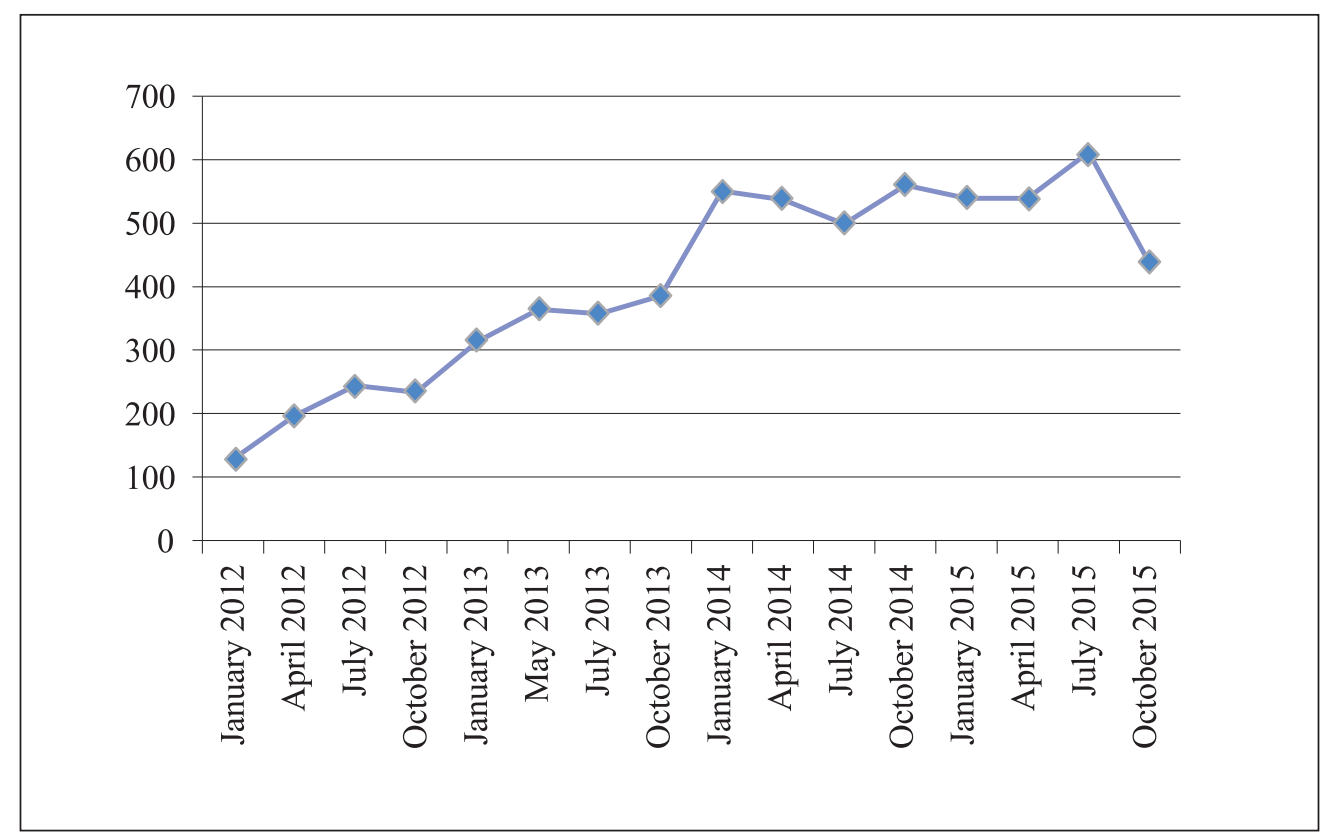

(Source) People's Bank of China.

Legal offshore centers supply many banks around the world with RMB, and the agreements brokered by the People's Bank of China (PBoC) with other central banks make provision for the use of credit lines to make RMB available to settle international trade (Ballantyne, Garner, and Wright 2013). Regardless of the different appraisals of economists regarding the resilience of capital controls, the RMB has now been able to attract demand and catch the eye of international financial actors beyond the mere prospect of speculative gains arising out of expectations of upcoming RMB appreciation, despite the non-convertibility of the Chinese currency. The Society for Worldwide 
Interbank Financial Telecommunication (SWIFT) indicates that in international trade deals passing through its network of interconnected banks, the RMB continues its steady growth. In January 2012, RMB has climbed its way from the twentieth to the fourth place in the ranking of international payments currencies, having outpaced the Swiss franc and the yen in October $2015^{7}$. Started in 2009 and bolstered by the 2014 opening of RMB hubs in European financial centers like London, Frankfurt, and Paris, the RMB keeps expanding in international exchanges. The share of RMB-settled trade deals relative to all of Chinese trade with the rest of the world amounted to a negligable percent in 2009, then rose to $8.8 \%$ in 2011, and almost 25\% in 2014 (Chinn and Ito 2014, PBOC). Figure 2 charts its remarkable surge since 2009.

\section{Figure 2. Cross-border trade settlement}

(billions of RMB)

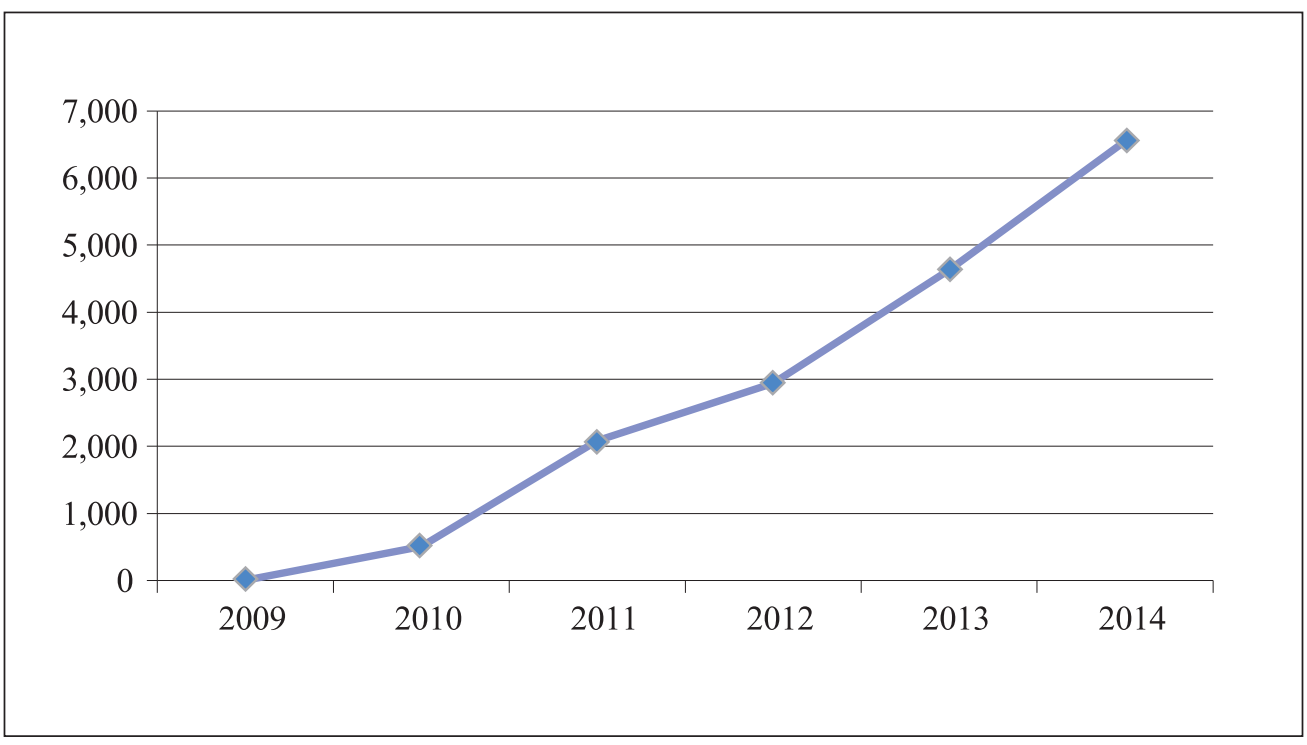

(Note) In the first half of 2014, RMB cross-border trade settlement reached 3.27 trillion RMB.

(Source) Rhee and Sumulong (2013) and People's Bank of China.

We have to qualify our conclusions by outlining that the RMB amounts to only

\footnotetext{
${ }^{7}$ The RMB returned fifth place at the end of 2015, following disappointing PBoC releases on RMB cross-border trade settlement. Despite this multiple digit growth of RMB use, we have to keep in mind that its share remains minor in the payments world: in value, the RMB amounts to $2.17 \%$ of payments within SWIFT compared to more than $28 \%$ for the euro and more than $44 \%$ for the dollar (Swift 2015).
} 
$2 \%$ of world payments, while the US Dollar is still the dominant currency even for China's cross-border trade. Furthermore, the Chinese economy has been recently hit by a financial crash and an economic slowdown. Given that the RMB is internationalizing primarily through international trade - particularly imports - the decrease of Chinese imports more than 5\% year-on-year since November 2014 is a bad sign for the RMB. Nevertheless, important institutional reforms like the implementation of a new payments system, i.e., Cross-border Inter-bank Payments System (CIPS) that will improve and facilitate RMB trade settlement shall eventually strengthen the RMB (PBoC 2015).

Additionally, the RMB has been included by the International Monetary Fund in November 2015 in the Special Drawing Rights (SDR) basket, joining the world's four major currencies. The SDR reform is expected to better depict the current patterns of the international economy by assigning to the RMB $10.92 \%$ of the basket, the third biggest share, after the US Dollar and the euro. The International Monetary Fund (IMF) eventually addressed the request made by Zhou (2009) after the 2008 crisis for well-representing SDR. The long road of RMB internationalization can be therefore considered as a success in facilitating a more balanced relationship between China and the US-dominated world within international organizations such as the IMF.

China's singularity could potentially move within the hierarchical structure of the current monetary system. This evolution, however, does not alter the fundamentally unequal nature of this structure as a whole. The following section, centered on the problem of international debt issuance, seeks to elaborate on this view.

\section{The Issue of International Debt Denomination}

In the framework of globalization, both public and private actors supply a significant portion of international debts. However, as with international trade invoicing, the denomination of bonds is limited to a few currencies, which is especially a matter of concern for developing countries. 


\section{A. Original sin and international debt issuance}

Original sin refers to the inability of many emerging and developing economies to borrow abroad in their own currencies. This is one of the key factors of their financial fragility (Ponsot 2015). Original sin has a negative impact on these economies in that it puts them at financial risk by creating a currency mismatch between their revenues collected in their national currencies and the financing of their activities in a foreign currency, mainly the euro and the US Dollar. In a much-celebrated article, co-authored by Panizza (Eichengreen et al. 2002), they relinquished what they had previously labelled the domestic component of original sin, that is, a situation in which the domestic currency cannot be used to take out long-term loans because of high-level domestic risks. They claimed that shortcomings in national macroeconomic policies and institutions were not statistically related with original sin and found that the size of a country was the only statistically robust determinant of original sin. Several measures of original sin (OSIN indexes) were devised in order to assess its intensity, determinants, and impacts with maximum accuracy.

Other parameters can have an impact on original sin, such as international transaction costs, network externalities, global capital-market shortcomings, monetary credibility, the exchange-rate regime, the level of the public debt burden, and the size of the investor base.

Yet, it has been argued that the literature on original sin overlooks some other important determinants such as the export-to-GDP ratio, holdings of international reserves and foreign assets, the depth and importance of local bond markets, and the presence of foreign banks lending in their local currencies rather than cross-border lending. Overall, debt composition and debt ownership ought to receive more attention (Dell'Erba et al. 2013).

\section{B. The case of Brazil}

A few emerging countries have endeavoured to counter the effect of original sin by unilaterally developing local-currency-denominated bonds at the international level. The most enlightening case is Brazil. In September 2005, the first large long-term debt issuance in the domestic currency was launched by the Brazilian government. This was part of a broader strategy aimed at reducing and improving the external public debt 
profile. It was well-received by foreign investors and expectations were high that the leading Latin American economy was en route to being redeemed of its original sin.

The first issuance of real-denominated international bonds (Global 2016) yielded a $12.5 \%$ yearly interest over 10 years (Tovar 2005) and the 200 international investors received a return of five times their original investments (1.5 billion US dollars). Even though this revolutionized Brazilian external debt management, at the end of the year the outstanding international government debt denominated in Brazilian reais represented only $2 \%$ of the total. In order to diversify the pool of investors the National Treasury issued global bonds. The issuance occurred simultaneously on and off-shore on Asian markets and concluded at closing on the US market, a mechanism called Green Shoe (Margolin 2007). For the Brazilian treasury, the purpose of this issuance was to familiarize international investors with the currency while protecting the local public market.

In 2006, the National Treasury continued its policy of qualitative improvement of the external debt profile, which led them to issue another global bond with the same profile of maturity and yield. As with the previous year, real-denominated bonds were massively purchased, which allowed the treasury to renew the issuance twice. In 2007, Brazil issued a real-denominated bond (Global BRL 2028) with a 20 year maturity period and a $10.25 \%$ annual coupon which reopened three times. With roughly 1.9 billion US dollars (1 US dollar $=2.0234$ Reais dollars) issued in reais, these local currency bonds accounted for $64 \%$ of the total international issuance. Still, in terms of volume the outstanding amount remains very close: 1.5 billion US dollars in 2005 and 1.4 billion US dollars in 2006.

Nevertheless, on the eve of the 2008 crisis the treasury's annual debt report praised Brazil's lasting ability to issue local currency bonds internationally and recalls Brazil's past woes when the country was afflicted with original sin. In 2008, adverse international conditions restricted the scope of Brazil's continuing external qualitative strategy. The international market conditions at the time prevented Brazil from borrowing in real on international markets. As for dollar liabilities, the treasury carried out a single operation of only 525 million US dollars on which it paid a historically low interest rate of a $6 \%$ coupon which the treasury called the deal of the year. Brazil did not issue local currency debt on international markets in 2009 either. As for the dollar-denominated bonds, the country benefited from its rating change from speculative to investment to issue bonds yielding interest rates even lower than those of 2008. In 2010, out of the four international issuances of sovereign bonds three were denominated in US Dollar and one 
in reais. As acknowledged by the 2010 annual debt report, the very low Fed funds rates created an appetite for the local currency bonds of emerging markets among international investors. This enabled Brazil to reopen its Global Brazil Rea (BRL) 2028 for 1.1 billion US dollars yielding roughly the same amount as the earlier 2007 issuance of $8.5 \%$. In 2011, in spite of yet another improvement of Brazil's external debt's rating and ever decreasing rates on its 30 year US Dollar-denominated bonds over the previous decade, Brazil did not issue debt in its own currency. External debt operations were denominated exclusively in USD. The National Treasury decided to purchase 11 billion of US Dollardenominated bonds so as to cover $49 \%$ of the external debt due by 2015 . In 2012, Brazil issued the Global BRL 2024 in reais for 1.7 billion US dollars and two issuances of US Dollar denominated bonds for 2.2 billion US dollars. The $53 \%$ of this local-currency issuance was aimed at repurchasing the bonds issued in 2005 and 2006 reaching maturity in 2016 and 2022. This was aimed to benefit from international demand to improve its external debt profile through its buyback program. Finally in 2013, Brazil did not issue bonds in reais on international markets.

\section{Private debt and original sin}

Regardless of whether the domestic or international market is involved, an increasing number of investors have been willing to take on the additional risk of currency denomination in the assets they hold. In keeping with original sin theory, currency trading is overwhelmingly concentrated in USD, euro, yen, and pounds sterling. Albeit insignificant, the Brazilian real did more than triple its share from 0.2 to $0.7 \%$ of foreign exchange trading between 2001 and 2010. The Brazilian real is now the leading Latin American currency for global bonds issuance with $0.25 \%$ of the world market, with Argentina and Mexico now issuing parts of their bonds in reais (Powell 2014). The rise of emerging currencies is not specific to Brazil, instead it shows that a shift has recently taken place in the international market architecture fuelled by low US interest rates.

Interestingly enough, although almost in contradiction with the conventional wisdom, an increasing number of international investors have moved directly to the Brazilian domestic markets. It is estimated that around $18 \%$ of local Brazilian bonds were held by international investors in 2012 (BNP Paribas 2013).

Brazilian public debt was not the only one to catch the eye of international buyers. Recent empirical studies have assessed the impact of original sin the business level as 
opposed to the state level. For instance, Brei and Charpe (2012) have looked closely at five episodes of currency collapse from the viewpoint of non-financial firms operating in Argentina, Brazil, and Mexico. At the business level, they found that the hardest hit for firms are those with high levels of unhedged foreign-currency debts. At the state level, Argentina, Brazil, and Mexico illustrate three contrasting trends. Argentina, unlike Brazil, is characterized by a large currency mismatch, and Mexico is halfway between the two. Brazilian firms have increasingly relied on bonds rather than loans in their international financing operations. Their US dollar-denominated debt tripled between 2004 and 2012. Private firms have been more prone to issuing a greater share of their debts in a foreign currency.

\section{Asymmetry of the international monetary system}

Looking at the predicament in the case of Brazil highlights the fact that the key feature of any successful issuance of real-denominated securities was that the country almost always did not need them. Large and strong domestic market associated with large capital inflows dramatically reduced Brazil's needs for external borrowing either in its own currency or in US Dollar. The several issuances made by Brazil have been oversubscribed by investors but the monetary denomination was charged with an additional premium, as compared with the cost of US Dollar securities or domestic market bonds. Even though the real is now the leading Latin American currency, its share in international asset denomination remains extremely scant (around $0.5 \%$ ). Moreover, in the post-2008 period, Brazil seems to have benefited in 2010 and 2012 from favourable international monetary conditions to issue new global bonds in reais. In other words, public debt issuance in the local currency may not have been as successful as it was believed to be, if we consider economic and financial indicators related to the acceptance and spread of Brazilian sovereign bonds issued in reais. If we also consider Brazilian firms' increasing dollar liabilities, it becomes glaring that original sin does not wash away easily but recurs.

Original sin is a solid example of the inertia and asymmetry embedded in the current international monetary system. While it is never truly a concern for the dominant international currency issuer and is of limited concern for some industrialized economies (the Euro area, Japan, Switzerland, and the UK), original sin is a significant problem for peripheral economies which cannot borrow abroad in their own currencies. The question 
of how emerging and developing economies could be rid of original sin has sparked much debate. The consensus view is to recommend that these countries accumulate large and expensive foreign reserves as a way of insulating themselves from potentiallydestabilizing financial trouble. Another view, endorsed by the G-20 in November 2011, involves a multilateral action plan to support the development of local currency bond markets in the hope that this would overcome the difficulties encountered by emergingmarket borrowers (IMF et al. 2013). A more promising multilateral solution would be to promote new regional financial architecture. One of the great ambitions of the Bank of the South, established in 2009 in South America, was precisely to put an end to the region's dependence on the US Dollar and augment mutual regional sources of revenue. By strengthening regional bond markets, it may alleviate the burden of original sin (Camara-Neto and Vernengo 2010).

\section{E. The case of China}

Countries which solve the problem of original sin are assumed to issue bonds in their own currencies internationally. The end of the first section emphasizes the specificity of RMB emergence which has enabled china to carry out cross-border trade in RMB. We will conclude our analysis by focusing on the similarities between that and China's issuance of international debt.

The country has long experienced twin surpluses. It does not rely on international investors due to the high saving rate of the Chinese population, and the trade surpluses which have generated huge foreign reserve stocks. However, both the Chinese public and the private sector issue bonds. Bonds are issued onshore, but also in a growing proportion in offshore markets in order to become available to non-Chinese portfolios. RMB-denominated offshore bonds are called dim sum bonds. The main offshore market for Chinese financial activities is Hong Kong, where the first dim sum bond was issued by the China Development Bank in July 2007. Since then, the market has grown strongly. 
Figure 3. Dim Sum Bond issuance

(billions of RMB)

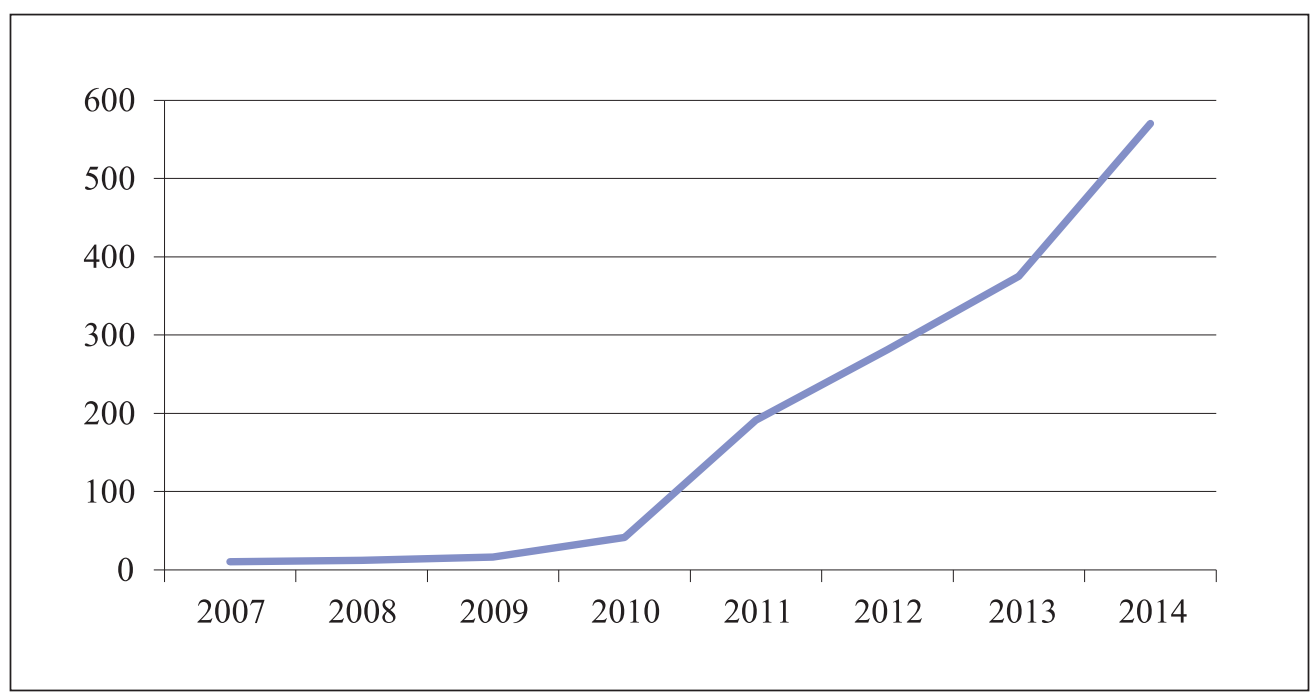

(Source) HSBC's forecast from Clearstream (2014).

The issuers were initially Chinese public institutions, which where progressively joined by state-owned enterprises and transnational foreign companies. In 2010 McDonald's became the first issuer outside China (Clearstream 2014). Other companies such as Caterpillar followed suit. In June 2014, the UK government issued dim sum bonds, which was a landmark. The above-mentioned inclusion of the RMB in the SDR basket should generate an additional external demand for RMB-denominated assets.

The development of the dim sum bond market is narrowly tied to the evolution of RMB cross-border trade settlement. Indeed, empirical studies have shown the main driver of the RMB internationalization to be trade settlement (Gagnon and Troutman 2014). The amount of outside RMB has been increasing as a result of the slackening of the controls on Chinese importers first and on Chinese exporters subsequently. This outflow of RMB is reflected by RMB deposits in Hong Kong.

The size of the RMB bond market is, as one might expect, closely linked to the amount of offshore RMB deposits. Dim sum bonds can be viewed as a tool for absorbing the growing amount of RMB deposits in offshore RMB platforms (Mathur and De 2014). These bonds enable RMB users to manage their RMB-trade incomes between new purchases and financial investments, through infrastructures provided by clearing institutions in Hong Kong (Rhee and Sumulong 2013). In reality, the amount of offshore 
RMB bonds issuances remains low because it is still costly to issue in RMB.

However, in the meantime, the RMB has gained a growing influence in Asia and the world. China is now able to issue bonds in its own currency, a sure sign of its monetary emergence.

\section{Conclusion}

The asymmetries of the international monetary system have been exemplified in this paper by international trade invoicing and international debt issuance. In both monetary practices, the US Dollar is currently the dominant currency. As a matter of fact, it is at the top of a hierarchy of currencies - similar to a pyramid (Cohen 2000) - whose foundations are made up of the currencies of developing countries. Right below the US Dollar, the intermediary level corresponds to the currencies of industrialized countries, like the euro, the pound sterling, or the yen. Of all the emerging countries, for the last several years China alone has been able to stand out, providing a rare example of internal mobility within that pyramid.

Not only is the current international monetary system sometimes viewed as cacophonic (Rossi 2009), but it also embodies a major constraint on the sovereignty of developing countries. It is for this very reason that some governments of developing countries have set out to challenge the US Dollar usage. Almost every attempt in the last few decades has failed. Asymmetries are seemingly a trap in that developing countries intent on avoiding top currencies inevitably encounter difficulties and their local currencies suffer from a lack of international confidence and from institutional concerns. China's case is of considerable interest in the study of the international monetary system's evolution: the emergence of China's economy begins to be mirrored in its cross-border monetary practices. China is also gaining ground in international organizations such as the IMF, as demonstrated the inclusion of the RMB within the SDR basket.

The future position of China in the hierarchy of currencies remains difficult to forecast as is the role it will adopt in the event of a reform of the international monetary system (Cohen 2014b, Jiang 2014, Chin 2014). The ascent China has experienced might not necessarily alter the fundamentally unequal nature of the structure as a whole. 
Received 7 April 2015, Revised 15 October 2015, Accepted 11 January 2016

\section{References}

Ballantyne, Alexander, Megan Garner, and Michelle Wright. "Developments in Renminbi Internationalisation." Reserve Bank of Australia Bulletin, June, (2013): 6574.

Bekx, Peter. "The implications of the introduction of the euro for non-EU countries." European Commission, Directorate-General for Economic and Financial Affairs, Brussels, 1998.

Benguria, Felipe, and Rodrigo Wagner. "How do Currencies Globalize? Firm-level Evidence on the early Adoption of the Euro." Paper presented at the annual meeting of the European Economic Association, Malaga, August 27-31, 2012.

BIS. "Financial stability and local currency bond markets." CGFS Papers, no.28, Committee on the Global Financial System, June, Basle, 2007.

BNP Paribas. EM Flows Tracker, 2013. globalmarkets.bnpparibas.com.

Brei, Michael, and Matthieu Charpe. "Currency depreciations, financial transfers, and firm heterogeneity." Emerging Markets Review 13, no. 1 (2012): 26-41.

Calabre, Serge. "La conjoncture sur les marchés internationaux de produits de base, contrainte pour le développement endogène.” Tiers-Monde 26, no. 104 (1985): 795807.

Camara-Neto, Alcino, and Matias Vernengo. "Beyond the Original Sin: a New Regional Financial Architecture in South America." Journal of Post Keynesian Economics 32, no. 2 (2010): 199-212.

Chin, Gregory. "China's Rising Monetary Power." The Great Wall of Money. Power and Politics in China's International Monetary Relations, edited by Eric Helleiner and Johnathan Kirshner, 184-212. Ithaca: Cornell University Press, 2014.

Clearstream. "Internationalizing the Renminbi: Weaving a Web for the Next World Currency." Aite Group white paper commissioned by Clearstream, 2014. 
Cohen, Benjamin. "Life at the Top: International Currencies in the Twenty-First Century." Princeton University Essays in International Economics, no. 221 (2000).

Cohen, Benjamin. "Will History Repeat Itself? Lessons for the Yuan." ADBI Working Paper Series, no. 453 (2014a).

Cohen, Benjamin. "The China Question: Can Its Rise Be Accommodated?" The Great Wall of Money. Power and Politics in China's International Monetary Relations, edited by Eric Helleiner and Johnathan Kirshner, 23-44. Ithaca: Cornell University Press, 2014b.

Dell'Erba, Salvatore, Ricardo Hausmann, and Ugo Panizza. "Debt Levels, Debt Composition, and Sovereign Spreads in Emerging and Advanced Economies." Center for International Development Working Paper, no. 263 (2013).

Dunajewski, Henri. "Choix de la monnaie de facturation et commerce de la France avec les pays de l'Europe de l'Est." Revue d'études comparatives Est-Ouest 16, no. 4 (1985): 87-107.

Eichengreen, Barry, Ricardo Hausmann. "Exchange Rates and Financial Fragility." National Bureau of Economic Research Working Paper, no. 7418 (1999).

Eichengreen, Barry, Ricardo Hausmann, and Ugo Panizza. "Original Sin: the Pain, the Mystery, and the Road to Redemption." paper presented at a conference on "Currency and Maturity Matchmaking: Redeeming Debt from Original Sin." Washington: Inter-American Development Bank, 2002.

Fabling, Richard, and Lynda Sanderson. "Export performance, invoice currency, and heterogeneous exchange rate pass-through." The World Economy 38, no.2, February (2015): 315-339.

Faudot, Adrien. “The Euro: An International Invoicing Currency?" International Journal of Political Economy 44, no. 1 (2015): 51-70.

Feige, Edgar, Vedran Šošiæ, Michael Faulend, and Velimir Šonje. "Unofficial Dollarization in Latin America: Currency Substitution, Network Externalities and Irreversibility." In The Dollarization Debate, edited by Dominick Salvatore, James Dean and Thomas Willett. Oxford: Oxford University Press, 2002.

Friberg, Richard, and Fredrik Wilander. "The currency denomination of exports. A 
questionnaire study." Journal of International Economics 75, no. 1 (2008): 54-69.

Gagnon, Joseph, and Kent Troutman. "Internationalization of the Renminbi: The Role of Trade Settlement." Policy Brief, no.14/15, Peterson Institute for International Economics, 2014.

Gnos, Claude, Virginie Monvoisin, and Jean-François Ponsot. "Regional Currencies and Regional Monetary Zones in Latin America: What Prospects?" Journal of Post Keynesian Economics 32, no. 2 (2010): 173-184.

Grassman, Sven. Exchange reserves and the financial structure of foreign trade: a study in commercial capital movements. Seminar Papers $\mathrm{n}^{\circ} 21$, Institute for international economic studies, Stockholm, November, 1972.

Grassman, Sven. "A Fundamental Symmetry in International Payment Patterns." Journal of International Economics 3, no. 2 (1973): 105-116.

International Monetary Fund, World Bank, European Bank for Reconstruction and Development and Organization for Economic Cooperation and Development. Developing Local Currency Bond Market: A Diagnostic Framework. Washington DC: International Monetary Fund, World Bank, European Bank for Reconstruction and Development, and Organization for Economic Cooperation and Development, 2013.

Ito, Hiro and Menzie Chinn. "The Rise of the "Redback" and the People's Republic of China's Capital Account Liberalization: An Empirical Analysis of the Determinants of Invoicing Currencies.” ADBI Working Paper Series, no. 473 (2014).

Ito, Takatoshi, Satoshi Koibuchi, Kiyotaka Sato, and Junko Shimizu. "Why has the yen failed to become a dominant invoicing currency in Asia? A firm-level analysis of Japanese Exporters' invoicing behavior.” NBER Working Paper, no.16231 (2010).

Jiang, Yang. "The Limits of China's Monetary Diplomacy." The Great Wall of Money. Power and Politics in China's International Monetary Relations, edited by Eric Helleiner and Johnathan Kirshner, 156-183. Ithaca: Cornell University Press, 2014.

Kamps, Annette. "The Euro as Invoicing Currency in International Trade." European Central Bank Working Paper Series, no. 665 (2006). 
Labaqui, Ignacio. "Who's Afraid of Reversing Neoliberalism? Financial Statecraft in Argentina and Venezuela." The Financial Statecraft of Emerging Powers, edited by Leslie Eliott Armijo and Saori Katada, 21-46. New York: Palgrave-Macmillan, 2014.

Lai, Edwin, and Xiangrong Yu. "Invoicing Currency in International Trade: An Empirical Investigation and Some Implications for the Renminbi." HKIMR Working Paper, no. 8 (2014) Hong Kong Institute for Monetary Research, April, 2014.

Looney, Robert. "Petroeuros: A Threat to U.S. Interests in the Gulf?" Middle East Policy 11, no. 1 (2004): 26-37.

Looney, Robert. "Iranian Oil Bourse: A Threat to Dollar Supremacy?” Challenge 50, no. 2 (2007): 86-109.

Mathur, Ike, and Soumen De. "The Dim Sum Bond Market in Hong Kong." Risk Management Post Financial Crisis: A Period of Monetary Easing, edited by Jonathan Batten and Niklas Wagner, 367-388. Bingley: Emerald Group Publishing Limited, 2014.

McKinnon, Ronald. The Unloved Dollar Standard: From Bretton Woods to the Rise of China. Oxford: Oxford University Press, 2013.

McKinnon, Ronald, and Gunther Schnabl. "China's Exchange Rate and Financial Repression: The Conflicted Emergence of the RMB as an International Currency." China \& World Economy 22, no. 3 (2014): 1-35.

Norrlof, Carla. America's Global Advantage. US Hegemony and International Cooperation. Cambridge: Cambridge University Press, 2010.

People's Bank of China (PBOC). China Monetary Policy Report, Quarter 2 - 2014, Beijing, August 1, 2014.

People's Bank of China (PBOC). "Milestone of RMB Internalization: RMB Crossborder Inter-bank Payment System Starts Operation.” Press release, October 14, 2015.

Ponsot, Jean-François. "Dollarization and the Hegemonic Status of the US Dollar." Monetary and Exchange Rate Systems: A Global View of Financial Crises, edited by Louis-Philippe Rochon and Sergio Rossi. Cheltenham: Edward Elgar, 2006.

Ponsot, Jean-François. "The four I's of the International Monetary System and the International Role of the Euro" Research in International Business and Finance 37, 
May (2016): 299-308.

Ponsot, Jean-François. “Original Sin.” The Encyclopedia of Central Banking, edited by Louis-Philippe Rochon and Sergio Rossi. Cheltenham: Edward Elgar, 2015.

Powell, Andrew. "Promoting the International Use of Emerging Country Currencies: The Case of Local Currency Debt Issuance for Latin America and the Caribbean." The BRICS and Asia, Currency Internationalization and International Monetary Reform, Paper no. 8, Asian Development Bank, The Centre for International Governance Innovation and the Hong Kong Institute for Monetary Research, 2014.

Prasad, Eswar. The Dollar Trap: How the US Dollar Tightened its Grip on Global Finance. Princeton: Princeton University Press, 2014.

Reiss, Daniel Gersten. "Invoice Currency in Brazil." University Library of Munich MPRA Paper, no. 59412 (2014).

Rhee, Changyong and Lea Sumulong. "A Practical Approach to International Monetary System Reform: Building Settlement Infrastructure for Reform." Asian Development Bank Economics Working Paper Series, no. 341 (2013).

Rossi, Sergio. "International payment finality requires a supranational central-bank money: reforming the international monetary architecture in the spirit of keynes" China-USA business Review 8, noll (2009) 1-20.

Smith, James. "World Oil: Market or Mayhem?” Journal of Economic Perspectives 23, no. 3 (2009): 145-164.

SWIFT. "RMB breaks into the top five as a world payments currency." http://www. swift.com, January 28, 2015.

Tovar, Camilo. "International Government Debt Denominated in Local Currency: Recent Developments in Latin America.” BIS Quarterly Review (2005): 109-118.

Tavlas, Georges. "On the International Use of Currencies: The Case of the Deutsche Mark." Princeton University Essays in International Finance, 1991.

UNCTAD. Trade and development report, Geneva, 2014.

Wilander, Fredrik. An empirical analysis of the currency denomination in international trade, manuscript. Stockolm: Stockholm School of Economics, 2006. 
Zhou, Xiaochuan. "Reform the International Monetary System." Essay by Dr. Zhou Xiaochuan, Governor of the People's Bank of China, March 23, 2009. 